\title{
Expression of E1E2 on Hepatitis C RNA-Containing Particles Released from Primary Cultured Human Hepatocytes Derived from Infected Cirrhotic Livers
}

\author{
Ndiémé Ndongo $^{\mathrm{a}, \mathrm{b}}$ Subjini Selliah ${ }^{\mathrm{d}}$ Pascale Berthillon ${ }^{\mathrm{a}, \mathrm{b}}$ \\ Valérie-Ann Raymond ${ }^{d}$ Christian Trépo ${ }^{a-c}$ Marc Bilodeau ${ }^{d}$ Marie-Anne Petit ${ }^{a, b}$ \\ a INSERM, U871, b Université Lyon 1, IFR62 Lyon-Est et ' Service d'Hépatologie, Hospices Civils de Lyon, Hôtel Dieu, Lyon, \\ France; ${ }^{d}$ Centre de Recherche du CHUM, Hopital Saint-Luc, Laboratoire d'Hépatologie cellulaire, Montréal, Qué., Canada
}

\section{Key Words}

Cirrhotic liver $\cdot$ E1E2 glycoproteins $\cdot$ Hepatitis $C$ virus .

Monoclonal antibody $\cdot$ Primary cultured human

hepatocytes

\begin{abstract}
Objective: To determine whether liver-derived hepatitis $C$ RNA-containing particles express the E1E2 discontinuous antigenic determinant defined by unique monoclonal antibody (mAb) D32.10 which recognizes three highly conserved segments in E1 (aa297-306) and E2 (aa480-494 and aa613621) envelope glycoproteins. Methods: Human hepatocytes were isolated from HCV-infected cirrhotic explanted livers. The liver-derived hepatitis $C$ virus $(\mathrm{HCV})$ particles released from three distinct cultures (genotypes $1 b$ and $2 b$ ) were characterized. HCV RNA+ was quantified by real-time RTPCR. The E1E2 antigenic activity was assessed by indirect ELISA and immunoblotting using D32.10. The density distributions of HCV RNA and E1E2 antigen were determined by isopycnic sucrose density gradients. HCV E1E2, E2 and core antigens were detected in the cells by immunochemical staining. Results: Liver-derived HCV particles contained HCV RNA $\left(10^{6}-10^{7}\right.$ copies/mg of protein) and core proteins and expressed the E1E2/D32.10 epitope. HCV RNA and E1E2
\end{abstract}

cosedimented between 1.15 and $1.25 \mathrm{~g} / \mathrm{ml}$ in sucrose gradients. Moreover, the mAb D32.10 detected E1E2 by immunostaining in $\mathrm{HCV}$-infected hepatocytes in parallel with $\mathrm{E} 2$ and core antigens. Conclusion: Our results provide evidence that the mAb D32.10 recognizes E1E2 envelope complexes expressed in the cell cytoplasm and on the surface of HCV RNAcontaining particles released from short-term cultures of in vivo infected hepatocytes.

Copyright $\odot 2010$ S. Karger AG, Basel

\section{Introduction}

Hepatitis $\mathrm{C}$ virus (HCV) is a positive-strand RNA virus that belongs to the genus Hepacivirus of the Flaviviridae family. This virus exhibits a narrow host (humans and chimpanzees) and tissue (hepatocytes) tropism. $\mathrm{HCV}$ is the most common blood-borne virus which causes chronic infections in approximately 170 million people in the world. Chronic hepatitis may progress to liver cirrhosis and hepatocellular carcinoma. Current therapies are limited, and only effective in $50 \%$ of infected patients depending on the genotype. A vaccine to prevent $\mathrm{HCV}$ infection is not yet available [for review, see 1]. The development of potential new antiviral therapies and

\section{KARGER}

Fax +41 613061234 E-Mail karger@karger.ch www.karger.com
(C) 2010 S. Karger AG, Basel

0300-5526/11/0541-0001\$38.00/0

Accessible online at:

www.karger.com/int
Marie-Anne Petit, $\mathrm{PhD}$

INSERM, U871

151, Cours Albert Thomas

FR-69424 Lyon Cedex 03 (France)

Tel. +33 47268 1958, Fax +33 47268 1971, E-Mail marie-anne.petit@inserm.fr 
a vaccine has been hampered by the difficulties to infect primary cultures of human hepatocytes by HCV-positive serum $[2,3]$.

In the last decade, significant progress has been made with the development of several HCV models: HCV-like particles produced in insect cells [4], HCV pseudotyped particles displaying E1 and E2 glycoproteins onto retroviral and lentiviral core particles [5], and cell culturegrown HCV ( $\mathrm{HCVCc}$ ) obtained after transfection of a unique HCV genotype 2a complete replicon (JFH-1) into Huh-7 or Huh7-derived hepatoma cells [6-8]. However, despite its strong advantages, the HCVcc model tightly depends on the JFH-1 nonstructural genes (replicase complex) of genotype $2 \mathrm{a}$ and the poor innate immune response characteristic of immortalized Huh-7 or Huh7-derived cells [9].

We have recently reported the feasibility of primary cultures of $\mathrm{HCV}$-infected human hepatocytes from cirrhotic livers removed at transplantation, and demonstrated that the morphological and functional properties of this system provide unique opportunities for studying HCV infection [10]. Moreover, we have previously characterized - for the first time - enveloped HCV particles in the serum of chronic hepatitis $\mathrm{C}$ patients, so-called HCVsp [11], thanks to unique monoclonal antibody (mAb) D32.10 which recognizes a highly conserved discontinuous antigenic determinant (E1:297-306, E2:480494 and E2:613-621) expressed on the surface of HCVsp from the main genotypes: 1a, 1b, 2a and 3a [12]. The availability of such systems prompted us to characterize the HCV RNA-containing particles released by primary cultures derived from in vivo $\mathrm{HCV}$-infected cirrhotic human hepatocytes.

\section{Materials and Methods}

\section{Isolation and Culture of in vivo HCV-Infected Human}

Hepatocytes

$\mathrm{HCV}$-infected human hepatocytes were isolated as previously described [10] from liver surgical biopsies of 3 different cirrhotic patients (informed consent was obtained from patients): two of genotype $1 b(\mathrm{P} 1$ and $\mathrm{P} 2$ ) and one of genotype $2 \mathrm{~b}(\mathrm{P} 3)$. Cells were seeded at a density of 50,000 cells $/ \mathrm{cm}^{2}$ in William's $E$ medium containing 10\% fetal bovine serum (FBS from Gibco BRL, Burlington, Ont., Canada). After $4 \mathrm{~h}$, the medium was replaced by fresh medium containing $10 \%$ human serum from HCV-negative donors, $4.5 \times 10^{-5} \mathrm{M}$ hydrocortisone and $1 \%$ dimethyl-sulfoxide. The supernatants collected from day 2 to day 7 after plating were clarified by centrifugation for $10 \mathrm{~min}$ at $20,000 \mathrm{~g}$ and stored at $-80^{\circ}$.
Purification of HCV Particles by Successive

Ultracentrifugation Steps

HCV particles from the three distinct liver cultures (P1, P2 and P3) were semi-purified from $50 \mathrm{ml}$ of supernatants by two sequential ultracentrifugations at $210,000 \mathrm{~g}$ for $4 \mathrm{~h}$ at $4^{\circ}$ in order to eliminate the cell culture medium as previously described [11]. The final HCV-enriched pellets (called VP1, VP2 and VP3, respectively) were resuspended in 1-2 $\mathrm{ml}$ of TNE buffer $(20 \mathrm{mM}$ Tris- $\mathrm{HCl}, \mathrm{pH} 7.5,100 \mathrm{mM} \mathrm{NaCl}, 1 \mathrm{mM}$ EDTA) and stored at $-80^{\circ}$ as small aliquots. Protein concentration was determined by BCA protein assay (Sigma Aldrich, Germany).

\section{Sedimentation Analysis: Buoyant Density Determination in}

Sucrose Gradients

To study the physicochemical properties of liver-derived HCV particles, each purified viral preparation (VP1, VP2 or VP3) was subjected to isopycnic centrifugation $\left(200,000 \mathrm{~g}\right.$ for $48 \mathrm{~h}$ at $\left.4^{\circ}\right)$ in a sucrose density gradient $(10-60 \% \mathrm{w} / \mathrm{w})$ in the SW41 rotor of a Beckman centrifuge. Fractions $(0.6 \mathrm{ml})$ were collected from the bottom of the tube, and the density of each was determined by refractometry. HCV-RNA content was assessed by branched DNA (b-DNA) technique and E1E2 antigenic reactivity analyzed by ELISA and Western blotting using the mAb D32.10.

\section{HCV RNA Quantification}

The quantification of HCV RNA in each of the different viral preparations (VP1, VP2 or VP3) as well as in the fractions from 3 distinct sucrose gradients was performed using the third generation of the b-DNA nucleic acid probe test (VERSANT HCV RNA 3.0 Assay; Bayer Diagnostics, Berkeley, Calif., USA). The assay required a sample volume of $50 \mu$ l. The lower and upper detection limits were $2.5 \times 10^{3}$ and $4.0 \times 10^{7}$ copies $/ \mathrm{ml}$, respectively, as mentioned by the manufacturer. The final detection was performed in a semiautomated Bayer System 340 b-DNA analyzer.

\section{E1E2 Antigenic Titration by Indirect ELISA}

E1E2 antigenic activity was determined as previously described [12]. Polyvinyl plates (Maxisorb, Nunc) were coated with the HCV final pellets VP1, VP2 or VP3 (from 6.25 to $200 \mu \mathrm{g}$ of protein $/ \mathrm{ml}$ ) or the fractions from sucrose gradients (dilution 1/5). The saturation was performed with TNB $(20 \mathrm{~mm}$ Tris- $\mathrm{HCl}, \mathrm{pH}$ $7.5,100 \mathrm{mM} \mathrm{NaCl}$ ) containing $5 \%$ bovine serum albumin. After four washings with TNB, the anti-E1E2/D32.10 mAb $(5 \mu \mathrm{g} / \mathrm{ml})$ was added and incubated at $37^{\circ}$ for $2 \mathrm{~h}$. The bound antibody was then detected with horseradish peroxidase (HRP)-conjugated anti-mouse immunoglobulins (1/5,000 Immunotech), and orthophenylenediamine as substrate. The reaction was stopped by adding $\mathrm{HCl} 2 \mathrm{~N}$ and the optical density was read at $490 \mathrm{~nm}$. The results were considered as positive $(\mathrm{P})$ when superior to the cutoff, corresponding to the mean of negative $(\mathrm{N})$ controls multiplied by 2.1 , i.e. $\mathrm{P} / \mathrm{N}$ ratio $>2.1$.

\section{Western Blot Analysis}

$\mathrm{HCV}$ envelope (E1 and E2) and core proteins were detected by immunoblotting using the $\mathrm{mAb}$ D32.10 [12] and rabbit polyclonal anti-core antibodies (C3, US Biological), respectively. Six micrograms of protein of each final HCV-enriched pellet (VP1, VP2 or VP3) and $10 \mu \mathrm{g}$ of different fractions from sucrose gradients were applied for the E1E2 detection. Fifty micrograms of protein of 
VP1, VP2 or VP3 were used to detect the core proteins. SDS-PAGE on $10 \%$ gel was performed under nonreducing and reducing conditions ( $2 \%$ SDS $\pm 5 \% 2 \beta$-mercaptoethanol) [11, 12]. After protein transfer onto polyvinylidene difluoride membranes, the mAb D32.10 $(5 \mu \mathrm{g} / \mathrm{ml})$ or C3 polyclonal antibodies $(1 \mu \mathrm{g} / \mathrm{ml}) \mathrm{di}-$ luted in $50 \%$ normal human serum were added as primary antibodies. In the revelation phase, HRP-conjugated anti-mouse (1/5,000 Immunotech) or anti-rabbit (1/10,000 Immunotech) IgG $\mathrm{F}\left(\mathrm{ab}^{\prime}\right) 2$ fragments were used, and the blots were revealed with an enhanced chemiluminescence detection system (ECL Plus system, Amersham Biosciences).

\section{Immunohistochemistry}

Hepatocytes isolated from two normal livers as negative controls (HCV-) and from two $\mathrm{HCV}$-infected cirrhotic livers $(\mathrm{HCV}+)$ corresponding to VP2 (genotype $1 \mathrm{~b}$ ) and VP3 (genotype $2 \mathrm{~b}$ ) were used for immunohistochemistry. Cells were seeded at a density of 50,000 cells $/ \mathrm{cm}^{2}$ and grown in four-well chamber slides (LaB-Tek, Brands Products). At day 3, cells were fixed with paraformaldehyde (2\% PFA in PBS) for $15 \mathrm{~min}$ at room temperature, washed threefold with $\mathrm{PBS}$ and stored at $-80^{\circ}$ until use. Immunostaining was performed using the Dakocytomation Envision dual link system HRP kit (Dako, Denmark). After permeabilization of cells with $0.1 \%$ saponine in PBS for $30 \mathrm{~min}$ at room temperature, and incubation with endogenous enzyme block for $10 \mathrm{~min}$ at room temperature, cells were incubated for 30 min with primary antibodies: the anti-E1E2/D32.10 mAb (2.5 $\mu \mathrm{g} / \mathrm{ml})$ or the anti-E2/D4.12.9 $\mathrm{mAb}(1 \mu \mathrm{g} / \mathrm{ml})$ or $\mathrm{mAb}$ to HCV core antigen (clone 11-B3, C8A216M, Biodesign International; $20 \mu \mathrm{g} / \mathrm{ml}$ ). Revelation was then performed by incubation with 3.3-diaminobenzidine $(\mathrm{DAB}+)$ substrate-chromogen for 5-10 min. The brown-colored precipitate at the antigen site was observed by light microscopy.

\section{Results}

Expression of the E1E2/D32.10 Epitope on the HCV

RNA-Containing Particles Released by Human

Hepatocytes Derived from HCV-Infected Cirrhotic

Livers

HCV particles released from primary cultures of human hepatocytes were semi-purified by sequential ultracentrifugation from supernatants collected on day 3 after seeding. This way, cellular material (debris) and proteins present in the culture medium were removed, and the pellet subjected to analysis represented HCV particle-enriched material. Three viral preparations (VPs) were obtained from three different patients: two of genotype $1 b$ (VP1 and VP2) and one of genotype $2 \mathrm{~b}$ (VP3). Their protein concentration was between 2 and $9.3 \mathrm{mg} / \mathrm{ml}$, and their HCV RNA content between $2 \times 10^{6}$ and $3.7 \times 10^{7}$ copies $/ \mathrm{ml}$ (or $4 \times 10^{5}$ and $7 \times 10^{6} \mathrm{IU} / \mathrm{ml}$ ), corresponding to around $10^{6}-10^{7}$ copies of HCV RNA per mg of protein (table 1).

Expression of E1E2 on HCV RNA

Particles from Infected Cirrhotic Livers
Table 1. Protein concentration and HCV RNA content of liverderived viral preparations (VP1, VP2 and VP3)

\begin{tabular}{llll}
\hline $\begin{array}{l}\text { HCV-lp } \\
\text { preparations } \\
\text { (genotype) }\end{array}$ & $\begin{array}{l}\text { Protein } \\
\text { concentration } \\
\mathrm{mg} / \mathrm{ml}\end{array}$ & $\begin{array}{l}\text { HCV } \\
\text { RNA } \\
\text { copies/ml }\end{array}$ & $\begin{array}{l}\text { HCV RNA/ } \\
\text { protein } \\
\text { copies/mg of } \\
\text { protein }\end{array}$ \\
\hline VP1 (1b) & 9.3 & $7 \times 10^{6}$ & $0.75 \times 10^{6}$ \\
VP2 (1b) & 2 & $2 \times 10^{6}$ & $\begin{array}{r}1 \times 10^{6} \\
\text { VP3 (2b) }\end{array}$ \\
\hline
\end{tabular}

Protein concentration was determined by BCA protein assay (Sigma Aldrich). HCV RNA was quantified using branched-DNA VERSANT HCV RNA 3.0 Assay (Bayer Diagnostics).

The HCV E1E2 antigenic activity of VP1, VP2 and VP3 was analyzed by indirect ELISA. The titration curve was established between 6.25 and $200 \mu \mathrm{g}$ of protein per $\mathrm{ml}$ (fig. 1A). The E1E2 reactivity decreased linearly from 200 to $12.5 \mu \mathrm{g} / \mathrm{ml}$. VP3 seemed to exhibit the strongest E1E2 reactivity. The limit of positivity was around $10 \mu \mathrm{g} / \mathrm{ml}$ for VP1 and $\leq 5 \mu \mathrm{g} / \mathrm{ml}$ for VP2 and VP3, which corresponded to $1-5 \times 10^{4}$ copies of $\mathrm{HCV}$ RNA. To confirm the expression of E1 and E2 glycoproteins, VP1, VP2 and VP3 were subjected to SDS-PAGE and Western blot using the mAb D32.10. As shown in figure $1 \mathrm{~B}$, both E1 $(31 \mathrm{kDa})$ and E2 $(60-68 \mathrm{kDa})$ proteins were clearly detected in the three HCV preparations. We noticed that there is good correlation between ELISA and Western blot techniques for the detection of E1E2 antigen (VP1 $<$ VP2 $<$ VP3), and more interesting between the E1E2 reactivity and the HCV RNA content (table 1). In addition, these results confirm that D32.10 detected the E1 and E2 proteins present in HCV particles obtained from genotype 2 as well as genotype 1 samples $[11,12]$. In order to determine whether these HCV particles contained core proteins, Western blot analysis was performed using rabbit polyclonal anticore antibodies $\mathrm{C} 3$. As shown in figure $1 \mathrm{C}$, the monomeric HCV core protein of $25 \mathrm{kDa}$ was only faintly detected in VP3 and not detectable in VP1, while a band at $50 \mathrm{kDa}$ was clearly observed in VP3, and a strong reactivity was visualized at $75 \mathrm{kDa}$ in VP1. Thus, it was difficult to conclude that these secreted particles contained core. In contrast, VP2 clearly expressed the HCV core protein of $25 \mathrm{kDa}$, as well as oligomeric forms at 50,75 and $150 \mathrm{kDa}$, as already described for serum-derived HCV particles [HCVsp, 11]. This confirms a great molecular heterogeneity of core proteins even under reduc- 


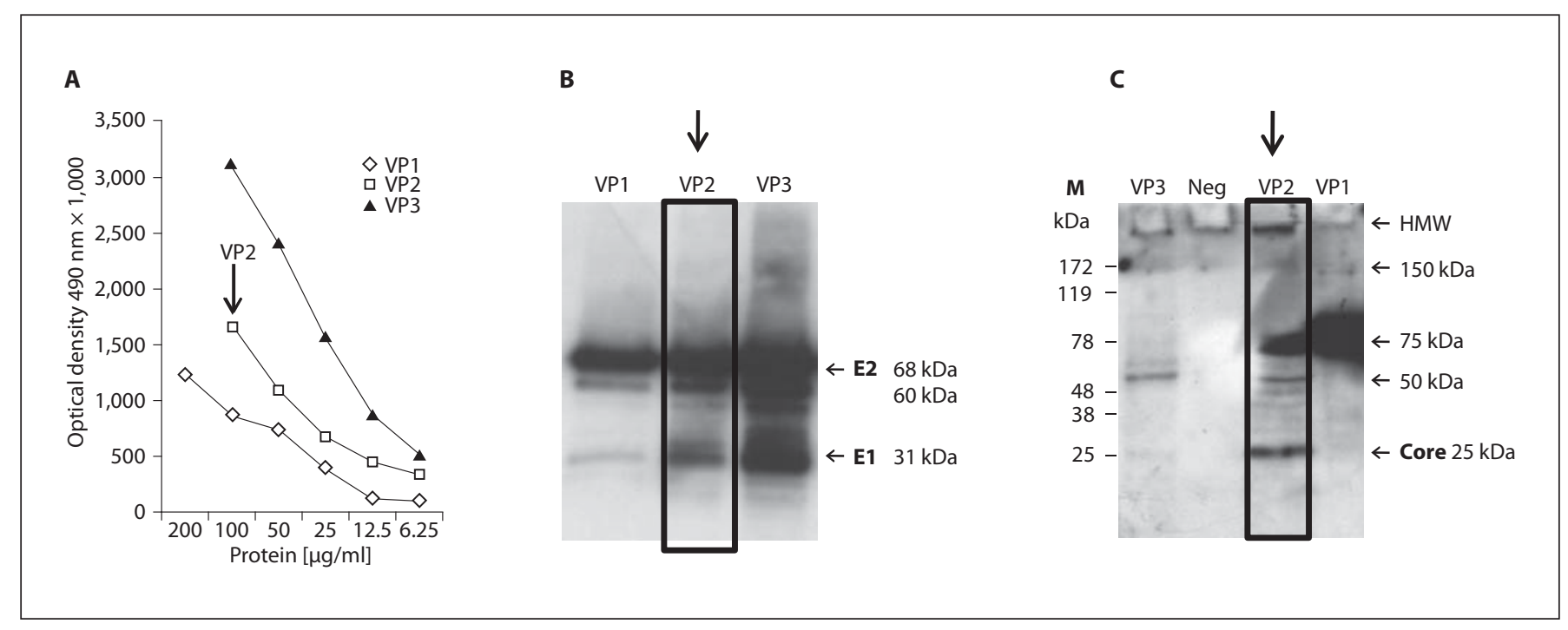

Fig. 1. Immunological characteristics of VP1, VP2 and VP3. A E1E2 antigenic titration of HCV-enriched pellets or VPs by ELISA. VP1, VP2 or VP3 were coated on solid surface at concentrations between 6.25 and $200 \mu \mathrm{g}$ of protein $/ \mathrm{ml}$. The mAb D32.10 was used as primary antibody at a concentration of $5 \mu \mathrm{g} / \mathrm{ml}$ in TN (20 mM Tris- $\mathrm{HCl}, \mathrm{pH} 7.5,100 \mathrm{mM} \mathrm{NaCl}$ ) buffer diluted in $50 \%$ of normal human serum. The optical density was read using a Multiskan Spectrometer (Thermo Electron Corporation) at $490 \mathrm{~nm}$. B Detection of E1 and E2 glycoproteins in VPs by Western blot. Six micrograms of protein of each VP were loaded on $10 \%$ gels in reducing conditions ( $2 \%$ SDS $+5 \% 2 \beta$-mercaptoethanol). E1 and

ing conditions in liver-derived HCV particles, as in HCVsp [11]. These results strongly suggest that VP2 corresponds to complete $\mathrm{HCV}$ virions released from infected hepatocytes in culture supernatant.

The density distribution of liver-derived HCV particles (VP1, VP2 and VP3) was then analyzed by isopycnic centrifugation in a sucrose density gradient (10$60 \%$; fig. 2A-C, respectively). For VP1 (fig. 2A, panel a), one major E1E2/D32.10-positive population with a density between $1.15-1.25 \mathrm{~g} / \mathrm{ml}$ was observed with a peak of HCV RNA in fractions 11 and 12 containing $1.4 \times 10^{5}$ and $3.3 \times 10^{4}$ copies $/ \mathrm{ml}$, respectively, i.e. approximately $2 \times 10^{5}$ copies of HCV RNA/ml in both fractions. For VP2 (fig. 2B, panel a) and VP3 (fig. 2C, panel a), a narrow E1E2/D32.10 peak was observed between 1.15 and $1.21 \mathrm{~g} / \mathrm{ml}$ and 1.15 and $1.18 \mathrm{~g} / \mathrm{ml}$, respectively. Fraction 12 (VP2; fig. 2B, panel a) and fraction 11 (VP3; fig. 2C, panel a) contained $3.8 \times 10^{4}$ and $3.3 \times 10^{4}$ copies of HCV RNA/ml, respectively. Selected fractions from sucrose gradients for each viral preparation (VP1, VP2 or VP3) were analyzed by immunoblotting using the $\mathrm{mAb}$
E2 proteins were detected by using the anti-E1E2/D32.10 mAb $(5 \mu \mathrm{g} / \mathrm{ml})$ and then blots were revealed with the ECL plus system (Amersham Biosciences) following the manufacturer's instructions. C Detection of core proteins in VPs by Western blot. Fifty micrograms of protein of each VP were loaded. Detection of HCV core proteins was performed by using rabbit polyclonal anti-core antibodies (C3; US Biological). Molecular mass markers (M) were indicated on the left and molecular weights of HCV-specific proteins were expressed in $\mathrm{kDa}$ and indicated on the right. $\mathrm{HMW}=$ High molecular weight; $\mathrm{Neg}$ = pellet from culture supernatants of noninfected liver transplants, i.e. negative control HCV-.

D32.10 under nonreducing (NR) and reducing (R) conditions (fig. 2A-C, panels b). In $\mathrm{R}$ conditions (lower panels b), the monomeric forms of E1 and E2 glycoproteins were maximally detected in fractions 11 and 12 for VP1 (fig. 2A, panel b), 11, 12 and 13 for VP2 (fig. 2B, panel b), and 10 and 11 for VP3 (fig. 2C, panel b), corresponding to peaks in ELISA (fig. $2 \mathrm{~A}-\mathrm{C}$, panels a). In NR conditions, only high molecular weight bands $(\geq 200$ $\mathrm{kDa}$ ) were observed, likely representing homo-heterodimeric forms of disulfide-bonded E1E2 envelope complexes (fig. $2 \mathrm{~A}-\mathrm{C}$, higher panels $\mathrm{b}$ ). In figure $2 \mathrm{~A}$, panel $\mathrm{b}, \mathrm{HCV}$-enriched pellet before sedimentation analysis was included as a positive control in the first lane. There is still a good correlation between the maximal detection of E1E2 envelope complexes and the presence of $\mathrm{HCV}$ RNA. All these signals are specific for $\mathrm{HCV}$ since no significant signal for both E1E2 in ELISA $(\mathrm{P} / \mathrm{N}<2.1$, fig. 2D) and HCV RNA in real time RT-PCR ( $<10$ copies $/ \mathrm{ml}$, not shown) was detected all along the gradient when HCV-negative control preparation was analyzed in parallel. These results show that the HCV RNA-pos- 


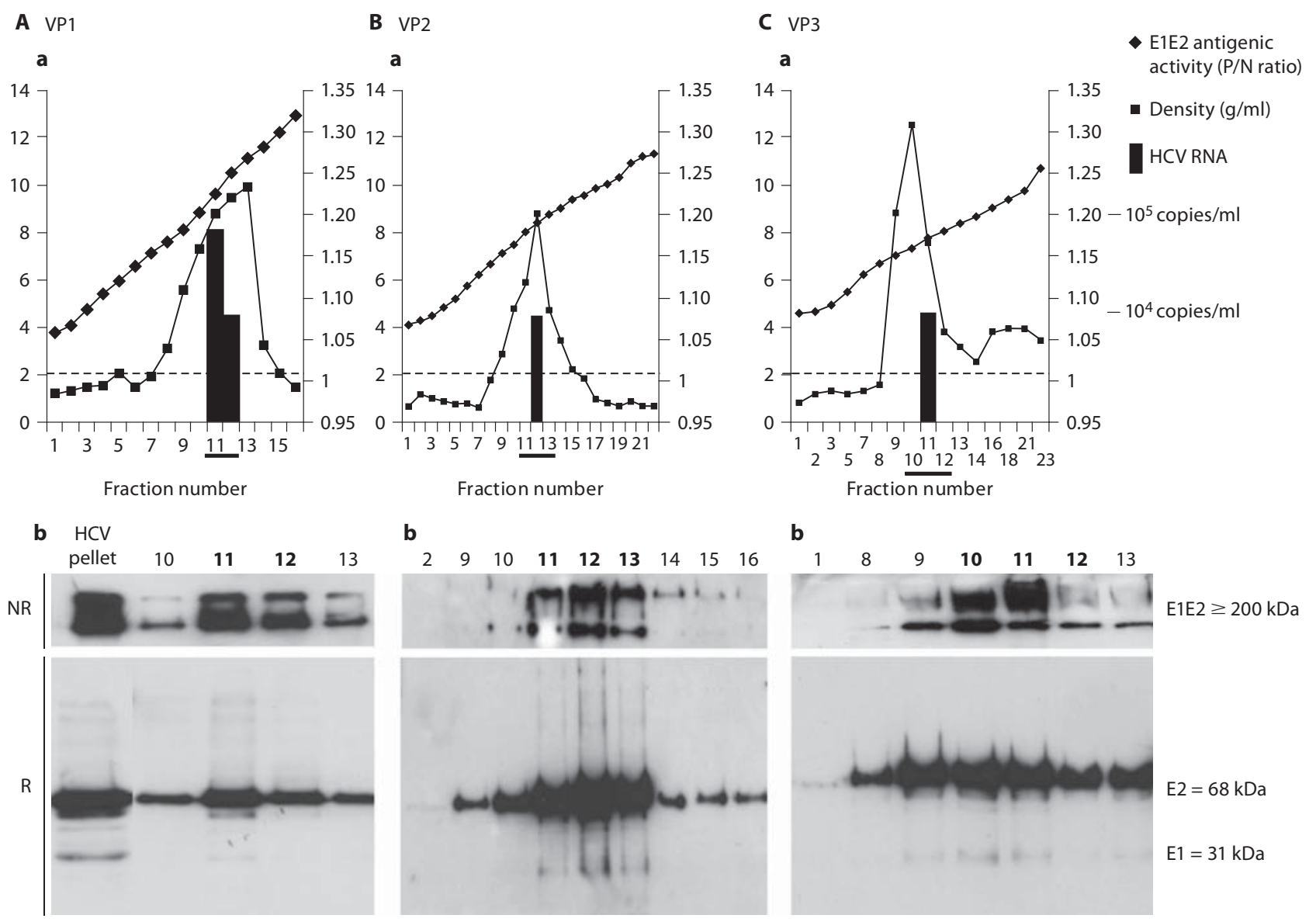

Fig. 2. Density distribution of liver-derived HCV particles. Panels a, isopycnic centrifugation in sucrose density gradient (10-60\%) of VP1 (A), VP2 (B) and VP3 (C). The density of fractions was determined by refractometry and expressed in $\mathrm{g} / \mathrm{ml}$ (right axis). All fractions were tested at the dilution of $1 / 5$ for E1E2 antigenic activity by indirect ELISA using the mAb D32.10. The results were expressed as $\mathrm{P} / \mathrm{N}$ ratio (left axis). The cutoff was visualized by a dotted line and corresponds to $\mathrm{P} / \mathrm{N}=2.1$. HCV RNA was analyzed in each fraction by b-DNA (Bayer Diagnostics, Berkeley, Calif., USA) and represented as dark bars. Panels $\mathbf{b}$, Western blot analysis of VP1 (A), VP2 (B) and VP3 (C). HCV pellet $(5 \mu \mathrm{g})$ and selected fractions $(10 \mu \mathrm{g}$ per lane) from the sucrose gradient (cf. panels a) were subjected to $10 \%$ SDS-PAGE under NR or R conditions. The HCV E1 and E2 proteins were detected using the $\mathrm{mAb}$ D32.10, and blots were developed with an enhanced chemiluminescence detection system (ECL plus system, Amersham Biosciences). Molecular weights of HCV-specific proteins were expressed in $\mathrm{kDa}$ and are indicated on the right of the gels. Negative control (HCV-; D) was obtained from noninfected liver and analyzed in a sucrose density gradient as in figure $2 \mathbf{A}-\mathbf{C}$. HCV RNA was tested in each fraction by quantitative real-time RT-PCR (detection limit $=10$ copies $/ \mathrm{ml}$ ) and found negative all along the gradient ( $<10$ copies/ml, not shown).

Expression of E1E2 on HCV RNA

Particles from Infected Cirrhotic Livers

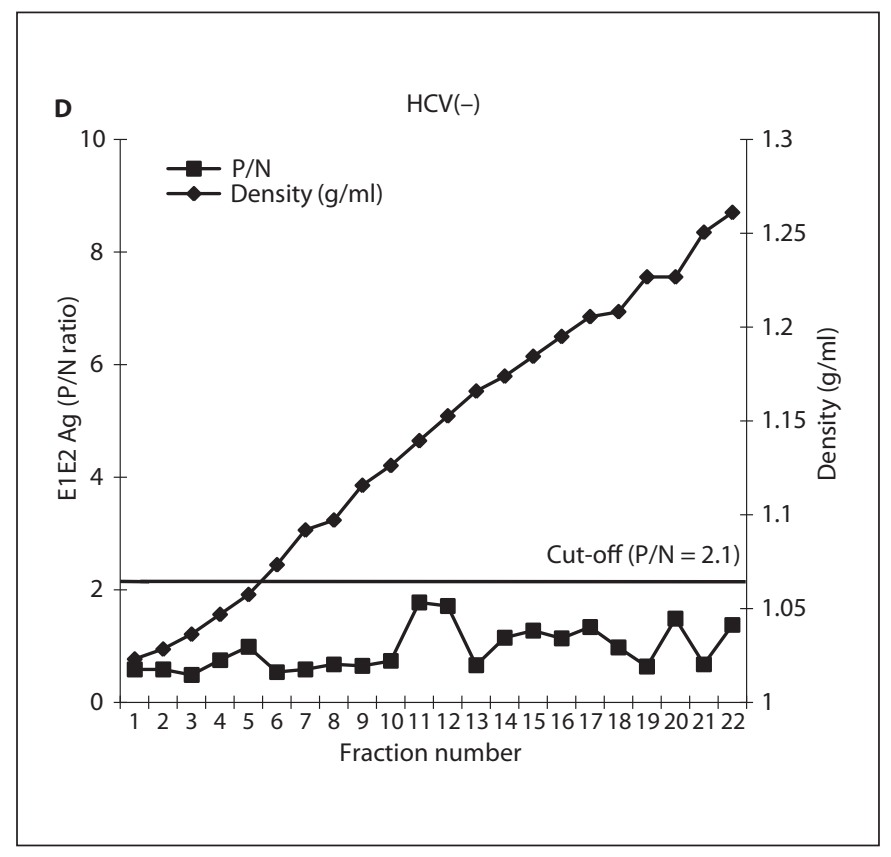

Intervirology 2011;54:1-9 


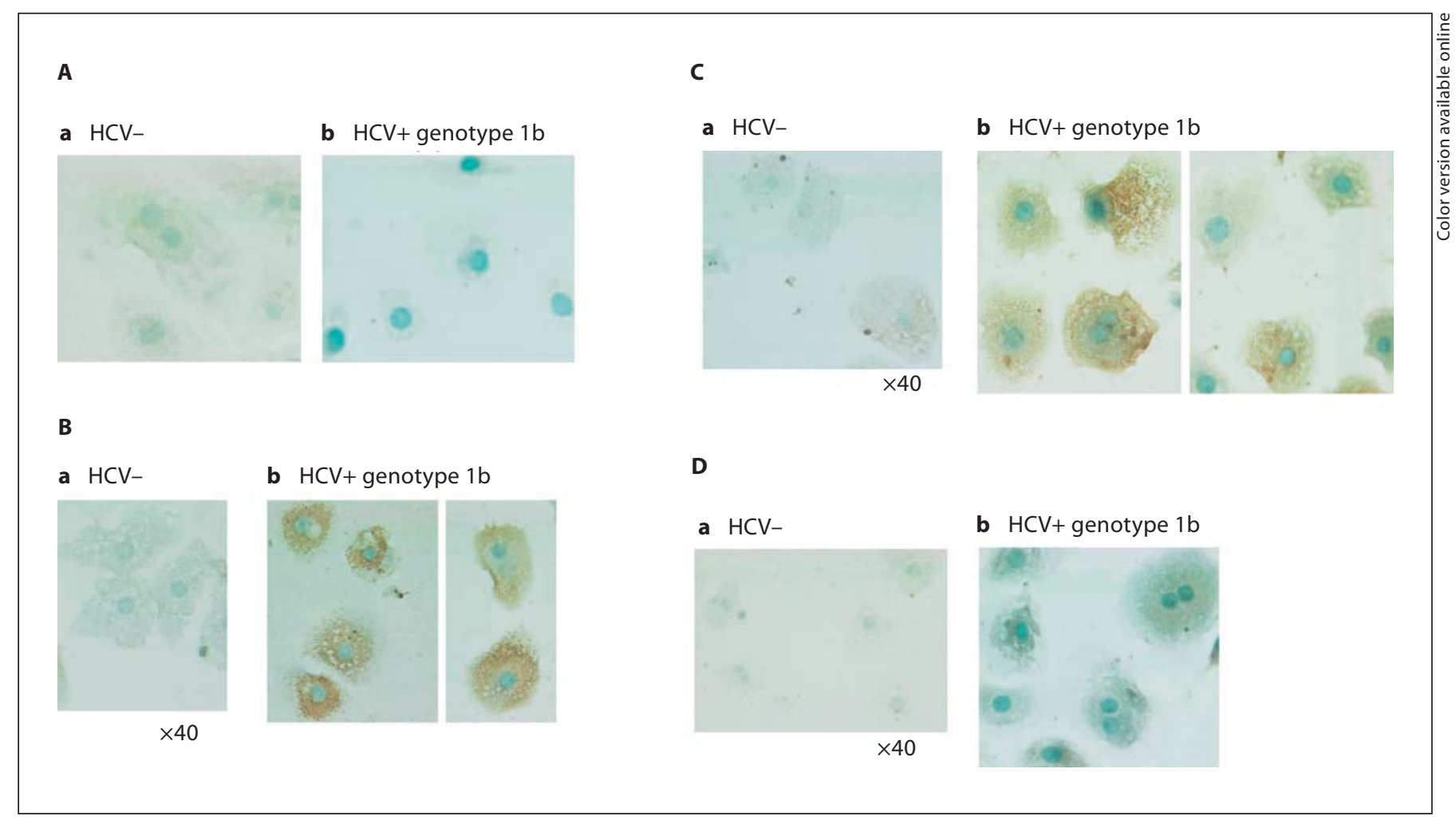

Fig. 3. E1E2, E2 and core antigen detection in HCV-infected hepatocytes by immunohistochemistry. Immunohistochemistry was performed in primary cultured hepatocytes derived from noninfected normal liver HCV- (panels a) and from liver chirurgical biopsy of cirrhotic patient HCV+ corresponding to VP2 of genotype $1 \mathrm{~b}$ (panels b). A Control irrelevant IgG1 primary anti- bodies $(5 \mu \mathrm{g} / \mathrm{ml})$. B Anti-E1E2/D32.10 mAb $(2.5 \mu \mathrm{g} / \mathrm{ml})$. C Anti$\mathrm{E} 2 / \mathrm{D} 4.12 .9 \mathrm{mAb}(1 \mu \mathrm{g} / \mathrm{ml})$. D Anti-core mAb (clone 11-B3, Biodesign International; $20 \mu \mathrm{g} / \mathrm{ml}$ ). The Dakocytomation Envision dual link system HRP kit (Dako, Denmark) was used for the revelation according to the manufacturer's instructions. The browncolored precipitate was observed by light microscopy. itive population released by human hepatocytes derived from HCV-infected cirrhotic livers (or HCV-lp) expresses the E1E2 epitope defined by the mAb D32.10 and sediments at a density of $1.15-1.25 \mathrm{~g} / \mathrm{ml}$ in a sucrose density gradient.

\section{Expression of the E1E2/D32.10 Epitope together with E2 and Core Antigens in Primary Cultured HCV-Infected Hepatocytes}

In control noninfected (HCV-) hepatocytes (fig. 3A$\mathrm{D}$, panels a), no or very low background was observed in the absence (control, fig. 3A) as well as in the presence of relevant primary antibodies (anti-E1E2/D32.10, fig. 3B; anti-E2/D4.12.9, fig. 3C, and anti-core, fig. 3D), even if some differences in brightness/contrast in the images could be observed. The results presented in figure $3 \mathrm{~A}-\mathrm{D}$, panels $b$, were obtained with hepatocytes derived from the $\mathrm{HCV}$-infected cirrhotic liver $(\mathrm{HCV}+)$ corresponding to VP2 of genotype $1 \mathrm{~b}$. A very strong specific staining with a cytoplasmic localization was observed in the presence of either the mAb D32.10 (fig. 3B, panel b) or the mAb D4.12.9 (fig. 3C, panel b). This demonstrates the expression of both E1E2 and E2 epitopes defined by each of these mAbs in HCV-infected hepatocytes from cirrhotic patients. Similar results for E1E2 (mAb D32.10) and E2 (mAb D4.12.9) were obtained with hepatocytes derived from the HCV-infected cirrhotic liver corresponding to VP3 of genotype $2 \mathrm{~b}$ (results not shown). $\mathrm{HCV}$ core antigen was also clearly detected in the HCVinfected hepatocytes corresponding to VP2 of genotype $1 b$, as shown in figure $3 \mathrm{D}$, panel $\mathrm{b}$. However, the $\mathrm{mAb}$ to $\mathrm{HCV}$ core antigen from Biodesign (recombinant $\mathrm{HCV}$ core antigen of genotype $1 \mathrm{~b}$ as immunogen) used here did not react with hepatocytes derived from the HCV-infected cirrhotic liver corresponding to VP3 of genotype $2 b$ (results not shown). These results support that the E1E2 
epitope recognized by the $\mathrm{mAb} \mathrm{D} 32.10$ is expressed in the cytosol of HCV-infected hepatocytes in parallel with E2 and core antigens.

\section{Discussion}

HCV preferentially infects and replicates in human or chimpanzee hepatocytes. A new model utilizing liver material obtained from HCV-infected patients [10] which more closely resembles the natural HCV infection provided a good opportunity for the analysis of the virus particles released from primary cultured human hepatocytes. Our objective was to investigate the expression of envelope proteins on the surface of liver-derived particles (HCV-lp) by using the unique mAb D32.10 which recognizes a highly conserved discontinuous determinant shared between E1 and E2 [12]. To this end, three different viral preparations: VP1, VP2 (genotype 1b) and VP3 (genotype $2 \mathrm{~b}$ ) from three different patients were analyzed for the E1E2/D32.10 antigenic reactivity in ELISA and Western blot. VP2 and VP3 exhibited a positivity in ELISA up to $6.5 \mu \mathrm{g}$ of protein $/ \mathrm{ml}$, which corresponded to $5 \times 10^{3}$ to $5 \times 10^{4}$ copies of HCV RNA or viral genome equivalents (vge), which was around the limit of detection of the b-DNA technique. This suggests that all HCV RNA-containing particles present in these preparations and released from infected hepatocytes express the D32.10 epitope on their surface. The detection in immunoblotting of both E1 and E2 monomeric forms under reducing conditions, and E1E2 oligomeric forms under nonreducing conditions supports such an assertion. Moreover, a close correlation was observed between the detection of HCV RNA and the E1E2/D32.10 antigenic activity.

HCV-specific core proteins as monomeric $(25 \mathrm{kDa})$ and oligomeric (multiple of $25 \mathrm{kDa}$ ) forms were clearly identified in HCV-lp present in the VP2 preparation. They are likely specific for the HCV capsid since no signal was observed with an HCV negative control (fig. 1C). These last results are in accordance with those previously found in serum-derived HCV particles (HCVsp) by using other anti-core $\mathrm{mAbs}$ for the revelation [11]. This supports molecular heterogeneity of HCV core proteins detected in Western blotting for the capsid from natural $\mathrm{HCV}$ particles derived either from liver or serum of $\mathrm{HCV}$ infected patients. The oligomeric forms of the HCV core protein could be detected even in the absence of monomers, as suggested by the results obtained from VP1 and VP3 preparations. The presence of key peptide sequences for initiating spontaneous multimerization in the C-terminal domain of the core protein (aa 125-179) has been shown [13]. Such oligomerization of the core protein to form capsid-like structures would be crucial for interaction with the cytoplasmic domain (aa 288-346) of the E1 envelope protein [14] during the assembly of HCV in normal human hepatocytes. Thus, the natural enveloped HCV particles could be more resistant to complete dissociation, even in the presence of reducing agents. It is also interesting to note that the monomeric form of the core protein we identified in natural serum- or liver-derived HCV particles has a molecular weight of $25 \mathrm{kDa}$ instead of $21 \mathrm{kDa}$ as expected. Although it has long been suggested that the precursor $25 \mathrm{kDa}$ core protein undergoes further processing into mature, functional unit of 21 $\mathrm{kDa}$, our observations may support a model proposed by Vauloup-Fellous et al. [15] according to which the precursor form may be the HCV core protein committed to virus particle morphogenesis, thus increasing the stability of the viral capsid. Our data show - for the first time that HCV RNA-containing particles released from primary cultured human hepatocytes derived from in vivoinfected cirrhotic livers express the unique E1E2 epitope recognized by the $\mathrm{mAb} \mathrm{D} 32.10$ and correspond to complete virions as identified in the VP2 preparation.

To further characterize the liver-derived HCV particles, the different VPs of genotype 1 or 2 were subjected to sucrose equilibrium density gradient ultracentrifugation. This separation strategy revealed the presence of only one major HCV RNA-containing population which expressed the E1E2/D32.10 epitope detected both in ELISA and in Western blot under reducing or nonreducing conditions. These liver-derived HCV RNA/E1E2+ particles exhibited a density between 1.15 and $1.25 \mathrm{~g} / \mathrm{ml}$. This fits in with the previous reports showing that the buoyant density of HCV virions released from hepatocytes into supernatant ranged from 1.16 to $1.20 \mathrm{~g} / \mathrm{ml}$ [16] corresponding to the density of other flaviviruses. More recently, by sucrose density gradient analysis of infectious cell culture grown HCV (HCVcc-JFH-1, genotype 2a) secreted by liver-derived cell lines (Huh7, HepG2 and IMYN9), the HCV core protein and RNA were recovered at a density of $1.15 \mathrm{~g} / \mathrm{ml}[6,17,18]$. To dissipate the possibility that the signal observed could be due to the presence of cellular material which could have the same density, a parallel analysis of non-infected ( $\mathrm{HCV}-)$ liver explants was performed, and no HCV-specific E1E2 or RNA signals could be detected throughout the gradient. Thus, we demonstrate that the HCV-lp exhibit similar physicochemical properties to recombinant $\mathrm{HCV}$ virions 
(HCVcc) as well as serum-derived HCV particles (HCVsp)

[11] when analyzed in a sucrose density gradient.

However, several papers have previously reported that $\mathrm{HCV}$ in patients' sera sedimented at a lower density $(\leq 1.10 \mathrm{~g} / \mathrm{ml})$ in association with very low-density lipoprotein as a lipid particle (LVPs for lipo-viro particles) containing triglyceride, phospholipid, ApoB and ApoE $[19,20]$. These LVPs have been shown to be not predominantly synthesized in the liver but may also originate in the intestine [21]. Recent results of Nielsen et al. [22] have indicated that the association between $\mathrm{HCV}$ and very low-density lipoprotein occurred in the liver. We noticed that in these studies $[20,22], \mathrm{HCV}$ has been purified by using isotonic iodixanol (Optiprep; Axis-Shield) gradients which are known to be superior to sucrose gradients in preserving the integrity of host lipoprotein-virus complexes. These differences in density distribution of $\mathrm{HCV}$ RNA in serum as well as in liver could be explained by the fractionation techniques used for the characterization of HCV particles. The iodixanol density gradients preserve the association of HCV with lipoproteins, while the sucrose density gradients could unmask the E1E2 envelope complexes without affecting their immunogenicity. Thus, the population of the virus characterized here corresponds to HCV RNA-containing particles expressing the E1E2/D32.10 epitope which could be associated with $A p o B$ and ApoE, in the same manner as viral par- ticles circulating in serum [Ndongo and Petit, unpubl. results].

Moreover, we showed the expression of the E1E2/ D32.10 epitope within HCV-infected human hepatocytes from cirrhotic livers in parallel with the one of $\mathrm{E} 2$ alone and core in immunostaining. Strong granular, cytoplasmic accumulation of HCV antigens was observed. These results are in accordance with those obtained previously in cirrhotic and tumoral liver sections [23]. They support that the mAb D32.10 as well as the mAb D4.12.9 recognize conserved epitopes and are powerful tools for detection of HCV envelope antigens independent of genotype in infected hepatocytes.

In conclusion, the conserved E1E2 original epitope defined by the mAb D32.10 is expressed within the HCVinfected hepatocytes and on the surface of liver-derived HCV particles as well as of circulating HCV particles [11]. These results reinforce the relevance of the mAb D32.10 for HCV studies and diagnostic approaches.

\section{Acknowledgments}

This study was supported by the Institut National de la Santé et de la Recherche Médicale and by grants from the Agence Nationale de Recherché sur le SIDA et les Hépatites Virales in France, and from the Canadian Liver Foundation in Canada.

\section{References}

1 Lindenbach BD, Thiel HJ, Rice CM: Flaviviridae: the viruses and their replication; in Knipe DM, Howley PM (eds): Fields Virology. Philadelphia, Lippincott-Raven, 2007.

$\checkmark 2$ Fournier C, Sureau C, Coste J, Ducos J, Pageaux G, Larrey D, Domergue J, Maurel P: Infection of adult normal human hepatocytes in primary culture by hepatitis $\mathrm{C}$ virus. J Gen Virol 1998;79:2367-2374.

-3 Rumin S, Berthillon P, Tanaka E, Kiyosawa K, Trabaud MA, Bizollon T, Gouillat C, Gripon P, Guguen-Guillouzo C, Inchauspé G, Trépo C: Dynamic analysis of hepatitis C virus replication and quasispecies selection in long-term cultures of adult human hepatocytes infected in vitro. J Gen Virol 1999;80: 3007-3018.

4 Baumert TF, Ito S, Wong DT, Liang TJ: Hepatitis $\mathrm{C}$ virus structural proteins assemble into virus-like particles in insect cells. J Virol 1998;72:3827-3836.

5 Bartosch B, Dubuisson J, Cosset FL: Infectious hepatitis $\mathrm{C}$ virus pseudo-particles containing functional E1-E2 envelope protein complexes. J Exp Med 2003;197:633-642.
6 Wakita T, Pietschmann T, Kato T, Date T, Miyamoto M, Zhao Z, Murthy K, Habermann A, Kräusslich $\mathrm{HG}$, Mizokami $\mathrm{M}$, Bartenschlager R, Liang TJ: Production of infectious hepatitis $C$ virus in tissue culture from a cloned viral genome. Nat Med 2005; 11:791-796.

7 Lindenbach BD, Evans MJ, Syder AJ, Wölk B, Tellinghuisen TL, Liu CC, Maruyama T, Hynes RO, Burton DR, McKeating JA, Rice $\mathrm{CM}$ : Complete replication of hepatitis $\mathrm{C}$ virus in cell culture. Science 2005;309:623626.

-8 Zhong J, Gastaminza P, Cheng G, Kapadia S, Kato T, Burton DR, Wieland SF, Uprichard SL, Wakita T, Chisari FV: Robust hepatitis C virus infection in vitro. Proc Natl Acad Sci USA 2005;102:9294-9299.

-9 Foy E, Li K, Sumpter R Jr, Loo YM, Johnson CL, Wang C, Fish PM, Yoneyama M, Fujita T, Lemon SM, Gale M Jr: Control of antiviral defenses through hepatitis $\mathrm{C}$ virus disruption of retinoic acid-inducible gene-I signaling. Proc Natl Acad Sci USA 2005; 102:29862991.
10 Raymond VA, Selliah S, Ethier C, Houle R, Jouan L, Maniere T, Lamarre D, Willems B, Bilodeau M: Primary cultures of human hepatocytes isolated from hepatitis $\mathrm{C}$ virus infected cirrhotic livers as a model to study hepatitis C infection. Liver Int 2009;29:942949.

11 Petit MA, Lièvre M, Peyrol S, De Sequeira S, Berthillon P, Ruigrok RW, Trépo C: Enveloped particles in the serum of chronic hepatitis C patients. Virology 2005;336:144-153.

-12 Petit MA, Jolivet-Reynaud C, Peronnet E, Michal Y, Trépo C: Mapping of a conformational epitope shared between E1 and E2 on the serum-derived human hepatitis $C$ virus envelope. J Biol Chem 2003;278:4438544392 .

13 Kim M, Ha Y, Park HJ: Structural requirements for assembly and homotypic interactions of the hepatitis $\mathrm{C}$ virus core protein. Virus Res 2006;122:137-143. 
- 14 Nakari K, Okamoto T, Kimura-Someya T, Ishii K, Lim CK, Tani H, Matsuo E, Abe T, Mori Y, Suzuki T, Miyamura T, Nunberg JH, Moriishi K, Matsuura Y: Oligomerization of hepatitis $\mathrm{C}$ virus core protein is crucial for interaction with the cytoplasmic domain of E1 envelope protein. J Virol 2006;80:1126511273.

-15 Vauloup-Fellous C, Pène V, Garaud-Aunis J, Harper F, Bardin S, Suire Y, Pichard E, Schmitt A, Sogni P, Pierron G, Briand P, Rosenberg AR: Signal peptide peptidase-catalyzed cleavage of hepatitis $\mathrm{C}$ virus core protein is dispensable for virus budding but destabilizes the viral capsid. J Biol Chem 2006; 281:27679-27692.

-16 Ito T, Mukaigawa J, Zuo J, Hirabayashi Y, Mitamura K, Yasui K: Cultivation of hepatitis C virus in primary hepatocyte culture from $\mathrm{pa}-$ tients with chronic hepatitis $\mathrm{C}$ results in release of high titre infectious virus. J Gen Virol 1996;77:1043-1054.
7 Parent R, Qu X, Petit MA, Beretta L: The heat shock cognate protein 70 is associated with hepatitis $\mathrm{C}$ virus particles and modulates virus infectivity. Hepatology 2009;49:17981809.

18 Akazawa D, Date T, Morikawa K, Murayama A, Omi N, Takahashi H, Nakamura N, Ishii K, Suzuki T, Mizokami M, Mochizuki H, Wakita T: Characterization of infectious hepatitis $\mathrm{C}$ virus from liver derived cell lines. Biochem Biophys Res Commun 2008;377: 747-751.

19 André P, Komurian-Pradel F, Deforges S, Perret M, Berland JL, Sodoyer M, Pol S, Bréchot C, Paranhos-Baccalà G, Lotteau V: Characterization of low- and very-low-density hepatitis $\mathrm{C}$ virus RNA containing particles. J Virol 2002;76:6919-6928.

20 Nielsen SU, Bassendine MF, Burt AD, Martin C, Pumeechockchai W, Toms GL: Association between hepatitis $\mathrm{C}$ virus and very-low-density lipoprotein (VLDL)/LDL analyzed in iodixanol density gradients. J Virol 2006;80:2418-2428.
21 Deforges S, Evlashev A, Perret M, Sodoyer M, Pouzol S, Scoazec JY, Bonnaud B, Diaz O, Paranhos-Baccalà G, Lotteau V, André P: Expression of hepatitis $\mathrm{C}$ virus proteins in epithelial intestinal cells in vivo. J Gen Virol 2004;85:2515-2523.

-22 Nielsen SU, Bassendine MF, Martin C, Lowther D, Purcell PJ, King BJ, Neely D, Toms GL: Characterization of hepatitis C RNA-containing particles from human liver by density and size. J Gen Virol 2008;89: 2507-2517.

23 Galy O, Petit MA, Benjelloun S, Chevallier P, Chevallier M, Srivatanakul P, Karalak A, Carreira C, Lyandrat N, Essaid A, Trepo C, Hainaut P, Chemin I: Efficient hepatitis C antigen immunohistological staining in sections of normal, cirrhotic and tumoral liver using a new monoclonal antibody directed against serum-derived HCV E2 glycoproteins. Cancer Lett 2007;248:81-88. 